DOI: 10.31866/2617-2674.4.2.2021.248749

UDC 791.228:7.012(477)

\title{
USE OF MOTION DESIGN ELEMENTS IN MODERN UKRAINIAN FILM AND TELEVISION PRODUCTION
}

\author{
Alla Medvedieva ${ }^{1 a}$, Iryna Burdiuh ${ }^{2 b}$ \\ ${ }^{1}$ PhD in Art Studies, Associate Professor; \\ e-mail: Aamedvedeva@i.ua; ORCID: 0000-0003-1422-7743 \\ ${ }^{2}$ Master's Student at the Cinema and Television Arts Department; \\ e-mail: iburdyuh@gmail.com; ORCID: 0000-0002-4382-4750 \\ a Kyiv University of Culture and Arts, Kyiv, Ukraine \\ ${ }^{b}$ Kyiv University of Culture, Kyiv, Ukraine
}

\section{Keywords:}

motion design;

animation graphics;

television ether;

film product;

computer animation

\begin{abstract}
The purpose of the research is to establish the role of motion design elements in Ukrainian cinema and television production, analyze the functions of motion design objects, find out the prcularities of their use in various audiovisual works. The research methodology is based on a theoretical analysis of film and television production, generalization of the main compositional and technical techniques of visual content, determination of their interdependence and role in the process of creating an audiovisual product. Scientific novelty. The components of the motion design in the modern Ukrainian cinema and television production have been analyzed for the first time, a detailed analysis of the interdependence of the structural components of the motion design in various audiovisual works has been carried out, their influence on shaped solutions of film and television products has been shown. Conclusions. In the course of the article, we analyzed the elements of motion design in Ukrainian cinema and television. In the process of studying cinema, television products, the basic principles of creating animation graphics in the Ukrainian film, and telepost have been established. Composite and technical components of motion-design, which affect visual solutions of an audiovisual work have been processed in detail and systematized.
\end{abstract}

For citation:

Medvedieva, A. and Burdiuh, I., 2021. Use of Motion Design Elements in Modern Ukrainian Film and Television Production. Bulletin of Kyiv National University of Culture and Arts. Series in Audiovisual Art and Production, 4(2), pp.260-269.

\section{Problem statement}

The field of motion design is one of the most dynamic in content marketing.
Today animated graphics are present wherever there is content: film industry (intros, captions, teasers, trailers), media (screensavers, captions, subtitles, visu- 
al design of programs), business (infographics, product presentations, websites), online games. These areas are characterized by constant development, which makes the profession increasingly popular.

To attract the attention of potential audiences, creators of audiovisual products are constantly looking for new ways to diversify their content. Dynamics, accessibility, clarity, informativeness, non-standard solutions for visual content, entertainment - these features make motion design a powerful tool for transmitting ideas and creating a unique video product.

Due to the growing attention to the use of motion design elements in the film industry and television, there is a need for a detailed analysis of animated graphics and the peculiarities of their use in various audiovisual works.

\section{Recent research and publications analysis}

M. Opalev, M. Murashko (2012) defined the concept of 'motion design' and systematize its objects.

The relevance of the use of motion design in video advertising of modern electronic devices is analyzed by M. Murashko (2014).

The role of animated graphics in the process of developing an individual visual style of the TV channel is clarified by M. Mozhenko (2018). The development of motion design elements was successfully described by V. Prokopchuk (2020). His work analyzes the principles of using animated graphics on the example of the most famous films of the world film industry.

The purpose of the research is to establish the role of motion design elements in Ukrainian film and television production, analyze the functions of motion design objects, find out the peculiarities of their application in various audiovisual works.

\section{Main research material}

Due to the ability of the brain to decipher the content of the image in a short period of time, communication that combines textual and graphical information is more effective than interaction using only text. Visualization of information is a powerful tool for translating ideas and opinions, which increases the level of clarity, accessibility, interest of information, emphasizing important details.

According to psychological research, 'people can remember an average of $20 \%$ of what they read. However, if the same information is converted into an image, the level of information retention will increase to $80 \%$ ' (2020, p.94). Motion design is used to visualize data on television and in the film industry.

Film critic M. Izvolov (2005, p.49) notes that 'subsonic cinema consisted of only two components: a moving image and ordinary fixed inscriptions. There were three types of titles: captions, intertitles (interframe captions) and subtitles (text in the frame)'. The first animated titles are found in the film 'The Man with the Golden Hand' (1955, director O. Preminger), for which graphic designer Sol Bass created an animation of white stripes, which, combined with musical accompaniment, turned into a hand. Thus, we can consider the date of the beginning of the development of motion design in the 1950s. Given this, it is important to emphasize the lack of a single definition of the concept. As of today, definitions of the term exist in the fields of design, film and television, design journalism.

Researchers M. Opalev and M. Murashko $(2012$, p.35) tried to give definitions 
of the concept of 'motion design': 'Motion design is an independent field of design aimed at designing branding objects and art objects using techniques and technologies of computer animation, sound design and interactivity, where visual effects, developed at the level of graphics, complement the plot with a new meaning'. Given the above, we can say that motion design is a weighty element of modern cinema. Scientists M. Opalev and M. Murashko point out that the elements of motion design, for example, subtitles, film's intro, visual effects, affect the disclosure of the plot, the clarity of the meaning of the picture, expand the information content of the film.

Given the fact that in the modern field of film production there is a rapid development of technologies for the use of animated graphics and visual effects, we define motion design as one of the modelling systems for filmmaking. Elements of motion design affect the dynamics of the film, composition, interaction of details, perception of time and other means of artistic expression.

V. Prokopchuk proposes to divide the types of inscriptions used in cinema into informational, containing data about the producers and participants in the process of making a film; discriptive-communicative, designed to describe the details of the plot, subtitles. However, the researcher notes: 'With the advent of sound in cinema, the second element became unnecessary, because the sounds could already be heard and did not need to be described, as well as a verbal communication of the characters, so came to the fore the information component of the film' (Prokopchuk, 2020, p.645).

It is necessary to agree with the opinion of the author stated above. Thus, at the current stage of cinema development, el- ements of motion design are part of the visualization of the film's plot.

M. Mozhenko (2018, p.334) proposes the following classification of movie titles:

1) initial titles;

2) title of the film;

3) title of parts of the film;

4) subtitles;

5) final titles.

According to this understanding, movie titles are a component of a director's idea, as researcher M. Mozhenko assures. 'Titles, in addition to a purely informative function, gradually began to bring emotional and semantic associations into the visual range of films, playing the role of a kind of graphic overture,-- says the author (Mozhenko, 2018, p.336).

In order to clarify the definition of the concept of 'animated captions', refer to the article 'Typographic aspect of animated captions in the cinema of the early digital age': Animated captions is artificially created with the help of various techniques and means of artistic expression' (Chuieva and Cholii, 2019, p.70).

Film theorist I. Weisfeld (1981) saw in the art of animated titles an attempt to give cinema associative thinking, to emphasize symbolism, to give screen objects the properties of the real world. We can agree with the researcher on the need to establish relationships between the film and life outside the film to increase the level of understanding of the content of the film by the audience.

Researcher M. Mozhenko (2018, p.336) emphasizes: 'Movie titles are an important component of the director's idea and in addition to a purely informational function, gradually began to bring emotional and semantic associations in the visual range of films, playing the role of a kind of graphic overture'. 
Analyzing the film directed by A. Seitablaev and J. Wynn 'Zahar Berkut' (2019, directors A. Seitablaev, J. Wynn), we can highlight the elements of motion design:

1) Titles: initial, film title, subtitles, final captions.

Initial captions contain information about the manufacturer and distributor. The film uses subtitles to be shown in cinemas. The final titles inform about the cast, members of the film crew. Note the stylization of the film fonts, visually reminiscent of printed books of the 19th century. Text animation is used to explain individual events of the film. Such text 'inserts' are made in orange shades, compositionally placed on the left side of the screen, while for the initial and final titles, white and the central location were chosen. Note the high degree of contrast of the orange text in combination with gloomy video footage, which adds expressiveness to the visual component of the film.

2) Particular attention is paid to the animation of the title of the film 'Zahar Berkut', which is made in 3D in the form of a burning stone. On the one hand, we trace the connection with the author of the novel 'Zahar Berkut', I. Franko, whom researchers call 'a stonemason' in their works. On the other hand, the symbolism of fire conveys the future mood of the film, immerses the viewer in the game plot. It is worth paying attention to the location of the letters ' $a$ ' and ' $x$ ', which are crossed like swords. This decision is part of the narrative of the film's future events used for the title of the film.

3) Animation and logo design of the manufacturer F\&P Media Group, made of stone material that emerges from a dark background and has a golden sheen with shades similar to those used for the title of the film.
4) Animation of fire sparks is part of the visualization of the plot.

5) Animation of clouds, fog, smoke. Motion design of these elements borders on the concept of 'visual effects'.

The motion design elements used in the film are stylized according to the visual decisions of the filmmakers, interact with the composition of the frame, are animated in accordance with the sound design, are integral components of the video series.

Different from the previous film is the visual solutions of the work of director A. Lukych 'My thoughts are quiet' (2019, director A. Lukych). A handwriting font is chosen for the captions. The title of the film is placed diagonally, an effect resembling an inscription with an aerosol can on the wall is added. This detail is used to reflect the 'note' of brawling in the soul of the protagonist. In the trailer, with the help of motion design, the plot of the tape is summarized: 'he writes the sound', 'they make a game', 'he has a dream', 'but there is still a mother', 'mom vs a dream'.

An additional element of motion design in the film is presented in the form of 'inserts' with black rounded vintage frames, reminiscent of the TV of the Soviet period, black and white frames of such a simulated TV stand out from the rest. The main purpose of this visual solution is a discourse in the childhood and youth of the protagonist: a pioneer camp, duck hunting and more. As the plot progresses, we observe a similar composition at the end of the film, when the cameraman, being in the car, where a significant part of the events takes place, records the conversation between the son and the mother. The shape of the car window frame resembles the screen of an old TV. This technique is used to create a sense of completeness in viewers, to ensure that 
the film events have become a historical past.

Analyzing motion design in the film industry, let's pay attention to its use in series. It should be noted that in the series motion design elements play an important role in creating the identity of the visual product. Animated graphics are present in captions, intros, program interfaces, as an element of visualization, for example, e-mail correspondence between characters.

An intro in the series is often a concentrate of creativity and visual expressiveness. The task of the intro is to immerse the viewer in a certain atmosphere in a few seconds, to convey the essence of the future story. The creators of foreign series use motion design for storytelling. The screensaver of the series 'Morning Show' (2019, directors M. Leder, D. Frenkel, etc.) is made in the form of animation of colourful balls. We trace the metaphor of the internal competition of the main characters of the series.

A similar principle is used in the series 'Unorthodox' (2020, director M. Schrader), about the life of a jew in Berlin. The creators of this intro have developed an animated map of the city without the names of streets and famous places, so that for the viewer the location remains unknown, as well as Berlin for the main character. The white moving line that paves the way between the grey squares, trying to 'escape' outside the frame, symbolizes the heroine of the story.

Studying the motion design of the Ukrainian-made series, we observe a similar trend. The creators of the Ukrainian TV series create screensavers, combining footage, animated text and graphics.

An example of the above statement is the screensaver of the series 'Trace'
(2020, directed by O. Goncharova). We define the motion design elements of the intro of this series: 3D-animation of the name of the detective agency 'OSA', animation of blood droplets, molecules under a microscope, broken glass, fingerprints, visualization of electromagnetic noise, computer code. As a result, the above-described elements of motion design of the intro 'Trace' indicate the genre of the series, the features of the storyline, create a tense atmosphere typical of detective work.

Captions, as part of the structure of motion design, are used in series to announce events, create the desired style of the historical period, emphasize the contradictions between the characters, the division of the series into episodes on various topics.

In the series 'Spiimaty Kaidasha' ('Catch Kaidash') (2020, director O. Tymenko) animated titles are dramatic elements that divide the story into separate parts, serve as a transition to certain time intervals. All titles of the video work, except for the title, are characterized by conciseness, simplicity, white color. To stylize the name, a font was chosen, which visually resembles the writing of the names of art books of the 19th century.

Note that the compositional elements of the frame in modern Ukrainian cinema synthesize the expressive means of cinema and motion design. This visual design increases the level of interest of the viewer, increases the interactivity and clarity of the audiovisual product.

In the field of television, motion design is used to create a branding of the TV channel, visual explanation of statistical data, visualization of difficult to understand information, attracting the attention of viewers through non-standard visual forms and solutions. 
Researcher A. Kurenkov (2015) identifies the following main elements of motion design in television programs: cap (screensaver), mirror (story announcement), reflection (heading announcement), curtain, profile (information about the guest of the program), hoarseness (photo by correspondent) during direct activation from the scene), geotag, titration die to represent a person in the frame, pop-up (several seconds announcement of the program or event), substrate (graphic background element), the layout of announcements, drum (final captions), closing screen saver (changed the screen saver of the program, which means the end of the program). At the end of the TV program, the screen shows the copyright of the channel and the year of production of the audiovisual product.

The duties of a motion designer on television include an animation of the above elements, as well as the creation of terrestrial identification of the channel (ID and promo).

According to M. Mozhenko, 'animated graphic elements play not only informational but also a certain aesthetic function, creating a graphic wrapper of the visual product, a certain visual image that subconsciously affects the viewer' (Mozhenko, 2018, p.335). It is worth agreeing with the author, because motion design on television, combining 2D and 3D graphics, text, footage of real events, perform informational and aesthetic functions.

I. Doronina describes television captions as an element of creolization, in other words, a combination of verbal and nonverbal means, in the communication system. 'During the one-sided use of text elements in conjunction with wellthought-out graphic and colour accompaniment, the director has the opportunity to achieve the necessary emotional response to their content,' - I. Doronina said (2019, p.149).

In the structure of the components of the motion design of the TV channel ' $1+1$ ', we can highlight the dynamic backgrounds with letters, square shapes, animation of the element of the logo ' + as a navigator. We note the use of red shades for the text, project logos, advertising banners on the site.

Elements of the motion design of the information program 'TSN' (TV channel ' $1+1$ ') are animation of images, infographics, statistics in the form of graphs, tables, charts. The informative function is performed by the animation of the titrating die and pop-up, subtitles in cases of poor quality of the recorded sound, help, geotagging, animation of movement on maps, etc. The information about the correspondent's location is placed at the right bottom of the frame along with the program name, which is placed at the left bottom of the screen.

Visual decisions of the 'STB' channel are determined by its content: family series, romantic, emotional shows, built around family values, love, empathy. 'In the concept of the new design, we are playing with the energy of the ocean. Our logo, as the main drop of this boundless ocean of love, overflows and fills with emotions. We also returned to the already familiar to the viewer branded warm colour palette 'STB', but implemented it in trendy tones,' - explains director of design 'StarLightMedia' O. Repik the concept of identity 'STB' (2020).

Next, we will analyze the elements of motion design of the program 'Viknanovyny' (TV channel 'STB'). The screensaver contains the name of the program, a geometric figure in the shape of a cube that mimics a globe, animation of lines going from the left part of the frame to 
the right, at the same time changing landscapes of cities; vertical sloping lines with a mirror effect, associated in the audience with the windows. The information content of the titles is similar to the previously analyzed program 'TSN'. However, we trace the differences in the visual design of text 'dice': opaque, the shape resembles a parallelepiped, the colour spectrum from dark red to pale yellow. Information about the correspondent's location is located at the top left. The name of the program, the name of the plot and the release date are located on a single 'die', separated by different colours.

A characteristic feature of the visual design of the TV channel 'ICTV' is the use of orange colour. Examples can be found in the logo, captions, subtitles, elements of advertising, design studios of the TV channel.

Elements of motion design of the information program 'ICTV Facts' (TV channel 'ICTV') are:

- screensaver, which according to the visual solutions used, resembles outer space with planets, around which the inscriptions 'economy', 'culture', 'technology', at the main headings of news releases; the combination of events from archival videos; 3D map of the world; animated program name,

- titration dies and pop-ups made on opaque rectangular elements, located in the central lower part of the frame, cover approximately $2 / 3$ of the screen width, which is much smaller compared to TV programs 'TSN' (TV channel ' $1+1$ ') and 'Windows of News' (TV channel 'STB'). The geotag is located at the top left. The name of the program is made in the form of an orange circle with the letter ' $F$ ' in white, located at the bottom right of the frame. 'ICTV' is characterized by a combination of black text on a white 'plate' with white text on an orange box;
- animation of images, infographics, statistics in the form of graphs, tables, charts.

A bright visual element of motion design, examples of which we see in the programs of all the above TV channels, is kinetic typography. The term combines the movement and deformation of the text in order to enhance the emotional content to attract the viewer's attention. The most common use of kinetic typography: captions, design of commercials, websites.

\section{Conclusions}

The development of the technological process continues to create innovative solutions in the world of motion design, which was born in the 20th century and still remains an important element in television and film production. It is worth noting that technological improvements have expanded the capabilities of audiovisual products creators in using tools to perform the functions of animated graphics.

The main objects of motion design in Ukrainian film and television production include an animation of captions, graphic elements, kinetic typography, simulation of natural phenomena, a combination of 2D and 3D graphics, creation of animation in combination with sound design.

It should be noted that the characteristic features of motion design are the conciseness of information, clarity of forms and means, diversity of visual content, effectiveness, emotion, originality and isolation of audiovisual work in the digital market. Based on the analysis of audiovisual products, we emphasize the unlimited use of animated graphics tools to integrate the viewer into the world of visual work. Following the above, we see the expediency of further analysis of the motion design elements in the Ukrainian film and television industry. 


\section{REFERENCES}

Chuieva, O. and Cholii, O., 2019. Typohrafichnyi aspekt animovanykh tytriv u kinomatohrafi pochatku tsyfrovoi doby [Typographic aspect of animated titles in the cinema of the beginning of the digital age]. Demiurge: ideas, technologies, perspectives of design, 2 (1), pp.67-80.

Doronina, I.M., 2019. Televizionnye titry kak element kreolizatcii v komynikativnom prostranstve [Television titles as an element of creolization in the communicative space]. In: Kommunikativnye tekhnologii v obrazovanii, biznese, politike i prave: problemy i perspektivy realizatcii v sovremennoi tcifrovoi srede [Communication technologies in education, business, politics and law: problems and prospects for implementation in the modern digital environment]. Materials of the V International Scientific and Practical Conference. Volgograd, Russia, 6-8 December, 2018. Volgograd: VGSPU, pp.147-150.

Izvolov, N.A., 2005. Fenomen kino [The phenomenon of cinema]. Moscow: Materik.

Kurenkov, A., 2015. Moushn-dizain v Adobe AfterEffects [Motion Design in Adobe AfterEffects] [video online] Available at: <https://www.youtube.com/watch?v=VTj9WwwgMos> [Accessed 14 April 2021].

Mozhenko, M.V., 2018. Tytry ta animovana hrafika v kino ta na telebachenni [Titles and animated graphics in film and television]. Mystetstvoznavchi zapysky, 33, pp.330-337.

Navchalnyi onlain kurs z pytan rozvytku vnutrishnikh komunikatsii v aparati Verkhovnoi Rady Ukrainy [Online training course on the development of internal communications in the staff of the Verkhovna Rada of Ukraine], 2020. Verkhovna Rada. [online] Available at: <https://eduhub. in.ua/files/161010576722458.pdf> [Accessed 14 April 2021].

Opalev, M.L., and Murashko, M.V., 2012. Opredelenie moushn-dizaina i sistematizatciia ego obektov [Definition of motion design and systematization of its objects]. Bulletin of Kharkiv state academy of design and arts, 6, pp.31-35.

Prokopchuk, V., 2020. Rozvytok elementiv moushn-dyzainu na prykladi naikasovishykh filmiv u sviti [Development of elements of motion design on the example of the highest-grossing films in the world]. InterConf, [online] 12 December 2020. Available at: <https://ojs.ukrlogos.in.ua/ index.php/interconf/article/view/6908> [Accessed 15 April 2021].

STB predstavyv novu efirnu hrafiku yak pershyi etap hlobalnykh zmin [STB presented a new broadcast schedule as the first stage of global change]. Broadcast, [online] 21 October 2020. Available at: <https://broadcast.net.ua/ru/news-broadcast/3246-stb-predstavil-novuyuefirnuyu-grafiku-kak-pervyj-etap-global-nykh-izmenenij> [Accessed 14 April 2021].

Vaisfeld, I.V., 1981. Iskusstvo v dvizhenii: Sovremennyi protcess. Issledovaniia, razmyshleniia [Art in Motion: Modern Process. Research, reflection]. Moscow: Iskusstvo. 


\title{
ВИКОРИСТАННЯ ЕЛЕМЕНТІВ МОУШН-ДИЗАЙНУ В СУЧАСНОМУ УКРАЇНСЬКОМУ КІНО-, ТЕЛЕВИРОБНИЦТВІ
}

\author{
Алла Медведєва ${ }^{1 a}$, Ірина Бурдюг²b \\ ${ }^{1}$ кандидат мистецтвознавства, доцент; \\ e-mail: Aamedvedeva@i.ua; ORCID: 0000-0003-1422-7743 \\ 2 магістрант кафедри кіно-, телемистецтва; \\ e-mail: iburdyuh@gmail.com; ORCID: 0000-0002-4382-4750 \\ а Київський національний університет культури і мистецтв, Київ, Україна

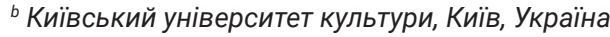

\begin{abstract}
Анотація
Мета дослідження - встановити роль елементів моушн-дизайну в українському кіно-, телевиробництві; проаналізувати функції об'єктів моушн-дизайну і з'ясувати особливості їх застосування в різних аудіовізуальних творах. Методологія дослідження ґрунтується на теоретичному аналізі кіно-, телепродукції, узагальненні основних композиційних і технічних засобів візуального контенту, визначенні їх взаємозалежності та ролі у процесі створення аудіовізуального продукту. Наукова новизна: вперше проаналізовано складники моушн-дизайну в сучасному українському кіно-, телевиробництві, проведено детальний аналіз взаємозалежності структурних компонентів моушн-дизайну в різноманітних аудіовізуальних творах і показано їхній вплив на образні рішення кіно-, телепродукції. Висновки. В статті проаналізовано елементи моушн-дизайну українського кіно і телебачення. У процесі дослідження кіно-, телепродукції встановлено основні принципи створення анімаційної графіки в українському кіно-, телепросторі. Детально опрацьовано та систематизовано композиційні й технічні компоненти моушн-дизайну, які впливають на візуальні рішення аудіовізуального твору.
\end{abstract}

Ключові слова: моушн-дизайн; анімаційна графіка; телевізійний ефір; кінопродукція; комп'ютерна анімація 


\title{
ИСПОЛЬЗОВАНИЕ ЭЛЕМЕНТОВ МОУШН-ДИЗАЙНА В СОВРЕМЕННОМ УКРАИНСКОМ КИНО-, ТЕЛЕПРОИЗВОДСТВЕ
}

\author{
Алла Медведева'а ${ }^{1 a}$ Ирина Бурдюг²b \\ ${ }^{1}$ кандидат искусствоведения, доцент; \\ e-mail: Aamedvedeva@i.ua; ORCID: 0000-0003-1422-7743 \\ 2 магистрант кафедры кино-, телеискусства; \\ e-mail: iburdyuh@gmail.com; ORCID: 0000-0002-4382-4750 \\ а Киевский национальный университет культуры и искусств, Киев, Украина \\ ${ }^{b}$ Киевский университет культуры, Киев, Украина
}

\begin{abstract}
Аннотация
Цель исследования - установить роль элементов моушн-дизайна в украинском кино-, телепроизводстве; проанализировать функции объектов моушн-дизайна и выяснить особенности их применения в различных аудиовизуальных произведениях. Методология исследования основывается на теоретическом анализе кино-, телепродукции, обобщении основных композиционных и технических приемов визуального контента, определении их взаимозависимости и роли в процессе создания аудиовизуального продукта. Научная новизна: впервые проанализированы составляющие моушн-дизайна в современном украинском кинотелепроизводстве, проведен детальный анализ взаимозависимости структурных компонентов моушн-дизайна в различных аудиовизуальных произведениях, показано их влияние на образные решения кино-, телепродукции. Выводы. В статье проанализированы элементы моушн-дизайна украинского кино и телевидения. В процессе исследования кино-, телепродукции установлены основные принципы создания анимационной графики в украинском кино-, телепространстве. Подробно обработаны и систематизированы композиционные и технические компоненты моушндизайна, которые влияют на визуальные решения аудиовизуального произведения.

Ключевые слова: моушн-дизайн; анимационная графика; телевизионный эфир; кинопродукция; компьютерная анимация
\end{abstract}

